\title{
CIRRPC
}

\section{FIFTH ANNUAL REPORT}

\author{
June 30, 1989
}

Alvin L. Young, Chairman

Committee on Interagency Radiation

Research and Policy Coordination

Office of Science and Technology Policy,

Executive Office of the President

Washington, D.C. 20506 
The Committee on Interagency Radiation Research and Policy Coordination (CIRRPC) is chartered through the Federal Coordinating Council for Science, Engineering, and Technology (FCCSET), Office of Science and Technology Policy, Executive Office of the President, Washington, DC 20506.

\section{NOTICES}

The opinions expressed herein do not necessarily reflect the opinions of the sponsoring institutions of Oak Ridge Associated Universities.

This report was prepared as an account of work sponsored by the United States Government. Neither the United States nor any of the agencies which are members of CIRRPC', nor any of their employees, makes any warranty, expressed or implied, or assumes any legal liability or responsibility for the accuracy, completeness, or usefulness of any information, apparatus, product, or process disclosed, or represents that its use would not infringe privately owned rights. Reference herein to any specific commercial product, process, or service by trade name, mark, manufacturer, or otherwise, does not necessarily constitute or imply its endorsement, recommendation, or favoring by the U.S. Govemment or any agency thereof. The views and opinions of authors expressed herein do not necessarily state or reflect those of the U.S. Government or any agency hereof.

This report was prepared under contract DE-AC05-760R00033 between the U.S. Department of Energy and Oak Ridge Associated Universities.

- Department of Agriculture, Commerce, Defense, Energy, Health and Human Services, Housing and Urban Development, Interior, Justice, Labor, State, Transportation, and Veterans Affairs, and the Environmental Protection Agency, Federal Emergency Management Agency, National Aeronauties and Space Administration, National Security Council, Nuclear Regulatory Commission, and Office of Management and Budget. 


\title{
COMMITTEE ON INTERAGENCY RADIATION RESEARCH AND POLICY COORDINATION
}

\author{
Fifth Annual Report
}

\author{
July 1, 1988 to June 30, 1989
}

\section{INTRODUCTION}

This is the fifth annual report of the Committee on Interagency Radiation Research and Policy Coordination (CIRRPC). CIRRPC was chartered April 9, 1984 under the Federal Coordinating Council for Science, Engineering and Technology (FCCSET) and reports to the Office of Science and Technology Policy (OSTP), Executive Office of the President. Its overall charge is to coordinate radiation matters between agencies, evaluate radiation research, and provide advice on the formulation of radiation policy.

Subcabinet and senior policy level representatives and senior scientists from member agencies constitute CIRRPC and its scientific component, designated as the Science Panel. There are eighteen CIRRPC member agencies at this time, with fourteen agencies having representatives on the Science Panel.

A listing of the Executive Committee members, agencies' representatives, and Science and Policy Panel participants are contained in Section V.A., V.B., and V.C. Oak Ridge Associated Universities' (ORAU) technical assistance staff and CIRRPC's reporting and organizational structure are contained in Sections V.D. and V.E.

\section{SUMMARY}

As CIRRPC moved into its fifth year of operation, and in preparation for the transition to a new Presidential Administration, the Executive Committee held a retreat of its members to review CIRRPC's performance and seek guidance on future activities. The retreat was held on July 21,1988 . To follow up on the retreat, an Ad Hoc planning group was established to develop a plan to address radiation issues that are important to the Nation. The Report of the Ad Hoc Planning Group was published in December 1988.

The report stressed that there are both broad and specific issues, some of which are extensions of ongoing activities, that need to be considered by CIRRPC. Of high priority to agencies is the development of consensus views on issues which involve both science and policy considerations, for example, on "acceptable risk," and the consistency of radiation protection standards (follow-up to "Fact Sheets" report). The role of CIRRPC in defining policy issues, identifying research gaps and objectives, and participating in public awareness and education requires reexamination of the "coordination only" and "low visibility" image presently in place. OSTP's support role should be addressed in this reexamination. Five issues were 
recommended for priority effort. They were:

- Commensuration Between Risks and Costs;

- Indoor Radon;

- Radiation Compensation;

- Radioactive Wastes; and

- Naturally Occurring and Accelerator-Produced Radioactive Materials (NARM).

Among a number of other topics suggested for future consideration by CIRRPC are non-ionizing radiation, food irradiation, public information and education, emergency preparedness, cleanup standards, and radiation measurements, records and control.

The review of the benefits, strengths, and weaknesses of CIRRPC lead to the overall conclusion that this valuable coordination activity should continue and, in fact, be strengthened. Increased member agency participation in policy decisions and in the initiation and overview of programs is needed to match the active role of the Science Panel and its subgroups. It was agreed that appropriate steps should be taken to assure adequate funding. A plan of action to address the issues identified would be developed by the Executive Committee, member agency volunteers, and the ORAU staff and submitted to the Policy Panel for discussion and approval. In acting on the recommendations of the Planning Report CIRRPC has taken the following actions:
- Established a working group to address the need for NARM regulations;

Established a science subpanel to facilitate the use of BEIR V and UNSCEAR 1988 Reports;

- Established a science subpanel to address the research needs related to occupational radiation protection;

- Established a subpanel to address policy issues associated with the use of the NIH Radioepidemiological Tables for adjudicating claims for alleged injuries; and

- Scheduled a discussion of radioactive waste cleanup standards with appropriate DOE officials at a meeting to be scheduled during the next reporting period.

During the past five years there have been fourteen reports completed and distributed. These reports are listed in Section IV.

\section{LOOKING AHEAD}

Several of the activities currently underway or being planned are expected to result in reports in the future. These are:

- The CIRRPC-sponsored BEIR V report by the NRC/NAS on the biological effects of low levels of ionizing radiation on populations, scheduled for issuance by the NAS in September 1989. 
- The report by the working group assessing the need for NARM regulations, scheduled for completion in January 1990.

- A CIRRPC-sponsored NCRP study on the use of collective dose in radiation protection and in assessing health risks.

- A report on the proposed increase in neutron quality factor.

- A report on advanced planning for health effects research following a major nuclear accident.

- A report on a research program that will provide a basis for more precisely determining the biological effectiveness of neutron radiation.

- Reports on the use of BEIR IV, BEIR V and UNSCEAR 1988 by the federal agencies in ionizing radiation risk assessment.

\section{LEGISLATIVE MONITORING}

Periodically the Executive Committee is briefed on the Congressional activities related to radiation matters which may be of interest to the member agencies. Among the topies covered by the legislative briefings during the past year were:

- Public Law 100-203, "The omnibus Budget Reconciliation Act of 1987," which reconstructed DOE's high level radioactive waste disposal program.
- Public Law 100-321, "Radiation Exposed Veterans Compensation Act of 1988."

- Public Law 100-408, "The PriceAnderson Amendment Act of 1988."

- Public Law 100-456, "The National Defense Authorization Act for Fiscal Year 1989," which added Chapter 21, "Defense Nuclear Facilities Safety Board."

- Public Law 100-551, "The Indoor Radon Abatement Act."

- Public Law 100-628, "The Homeless Assistance Amendments Act of 1988." Section 1091, established the HUD policy on radon contamination in housing owned by HUD.

- H.R.1547, "Standard Nuclear Reactor Development Act of 1989."

- H.R.1643, which contains five titles:

1. Establish an independent "Nuclear Weapons Production Health and Safety Board."

2. Require that new DOE production and utilization facilities be subject to licensing by the Board.

3. Amend the Clean Water Act and the Solid Waste Disposal Act to cover wastes that include byproduct, source, and special nuclear material.

4. Transfer to HHS the DOE epidemiological studies of the effects of radiation. 
5. Require DOE's Assistant Secretary responsible for environmental protection to be responsible for cleanup and remediation of DOE's facilities, and require the appointment of a DOE Safety Officer with authority to order shutdown of facilities.

- H.R.2480, "The Uranium Enrichment Reorganization Act."

- S.547, "Radiation Victims Fair Treatment Act."

- S.972, "Radiation Research Reorganization Act of 1989."

\section{BRIEFINGS AND MEETINGS}

During the past year there were 54 meetings, including meetings of the CIRRPC members, the Executive Committee, the Science Panel, and the Science and Policy Subpanels. In addition, there were a number of meetings and briefings involving members of the Executive Committee and representatives of member agencies.

- $\quad$ On February 7, 1989, Dr. Young met with Henry Singer, Director of the Safety and Environmental Management Division, General Service Administration, GSA, and his staff to discuss the implementation of the GSA Radon Protection Program for federally owned or leased facilities.
On April 18, 1989, Dr. Young met with Leo Duffy, Special Assistant to the Secretary of Energy for Defense Waste Management, to familiarize him with the activities of CIRRPC and invite him to present to CIRRPC the elements of the DOE Five Year Plan for Nuclear Defense Waste Cleanup when it is completed in the late summer.

At the request of the Assistant Associate Director for Natural and Technology Hazards, Federal Emergency Management Agency, FEMA, Dennis Kwiatkowski, members of the Executive Committee met with him and the FEMA staff on April 26, 1989, regarding coordination of agency comments on the EPA proposed issuance, for interim use, of a revised "Manual of Protective Action Guides and Protection Actions for Nuclear Incidents (PAGS)."

- At the invitation of Mr. Kwiatkowski the Executive Committee attended the June 5, 1989 meeting of the Federal Radiation Protection Coordinating Council (FRPCC) to hear the EPA briefing on its "Manual of Protective Action Guides and Protection Actions for Nuclear Incidents (PAGS)." 


\section{OPERATIONS}

\section{NATIONAL RESEARCH COUNCIL - BEIR V REPORT}

The National Academy of Sciences, National Research Council's report on the biological effects of ionizing radiation, BEIR $V$, is expected to be published in September 1989. This comprehensive review, interagency funded by CIRRPC, will provide up-to-date risk estimations to be used in assessing potential health effects from exposure to ionizing radiation. In addition to consideration of findings from many epidemiological and experimental studies, the review will reflect the most recent findings from analysis of the dosimetric and medical data collected in studies of the Japanese atomic bomb survivors. This authoritative report is expected to have a profound effect on health risk assessments of radiation exposure in the U.S. and on the control of radiation sources. CIRRPC has established a science subpanel on the use of the BEIR V Report and the 1988 UNSCEAR Report in federal risk assessments.

\section{HIGH-LET RADIATION}

The Subpanel on High-LET Radiation continues to oversee an international task group which has been identifying and prioritizing research needed to improve the scientific data base on the biological effectiveness of neutrons. The task group includes members from both the U.S. and European research communities. The group has identified research needs in the areas of physics and dosimetry, modeling, chemical and molecular mechanisms, cellular effects, nonstochastic effects in tissues and organs, and late effects in populations, including carcinogenesis, life span shortening, and hereditary effects. Their report will be released following a Fall 1989 meeting to finalize the summary of needed research, the overall research priorities and the recommendations.

\section{OCCUPATIONAL RADIATION PROTECTION RESEARCH}

On September 26, 1988, the Science Panel appointed an Ad Hoc Group, chaired by Mr. R. Thomas Bell, to explore intraagency interest in establishing a science subpanel on occupational radiation protection research. In February of 1989 the Ad Hoc Group submitted its report which included background on the problem, a prepared Work Statement, and a suggested role for a formal subpanel. The Subpanel was to identify common research needs in operational radiation protection programs of the federal agencies. The Subpanel was established and is actively identifying research needs in operational radiation protection programs of both federal and outside agencies.

\section{AD HOC PLANNING GROUP}

The Ad Hoc Planning Group, chaired by Colonel George W. Irving III, prepared recommendations on approaches to achieving short and long range goals important to the Nation's radiation agenda. This report was forwarded to all CIRRPC members and Dr. William R. Graham in December of 1988. 
NATURALLY OCCURRING AND A C CELERAT OR - PR O D U CED RADIOACTIVE MATERIALS (NARM)

By letter, dated July 26, 1988, the Chairman of the U.S. Nuclear Regulatory Commission (NRC) requested the Director of the Office of Science and Technology Policy to have CIRRPC examine the issue of whether discrete NARM sources, such as radium containing devices, should be regulated. Because of long-standing interests of states in this issue, the NRC letter included a request that CIRRPC consult with the Conference of Radiation Control Program Directors (CRCPD) in its deliberations. A working group was established to develop such report, under the Chair of Dr. Mary Carter, USDA's representative to CIRRPC. Other members represent DOE, NRC, HHS (FDA), EPA, DOL, DOD and DVA. Mr. Terry Strong, Director, Radiation Protection Program, State of Washington, briefed the Subpanel on states' interests in NARM and CRCPD's proposed plan for addressing both discrete and diffuse (e.g. waste piles from metal extraction processes) sources. The CRCPD plan would reflect the states taking a more direct responsibility for controlling NARM sources and their working closely with CIRRPC in its development of a report to the NRC. The Subpanel expects to complete its report as scheduled in early 1990.

\section{TRANS URA N I CS IN THE ENVIRONMENT}

In January 1988 EPA asked Dr. William Graham, Director of OSTP, to define unresolved issues involved in draft guidelines on transuranics in the environment. This request was transmitted to CIRRPC for action. The report of an
Ad Hoc Group on the subject was transmitted to EPA in August 1988 by Dr. Graham.

\section{PRE-DISASTER PLANNING FOR HUMAN HEALTH EFFECTS RESEARCH: A FEASIBILITY STUDY}

A complete draft report of the Subpanel, chaired by Mr. Charles Eisenhauer, was sent to the Science Panel in February 1989 for review and comment. The draft report addressed the issues raised in the review and recommended future federal actions to gather vital information in the event of any radiation accident. The report is to be submitted to the Science Panel for approval in August 1989.

\section{IONIZING RADIATION RISK ASSESSMENT, BEIR IV}

The Subpanel continued its review of the NRC/NAS report entitled, "Health Risks of Radon and Other Internally Deposited Alpha-Emitters, BEIR IV." The Subpanel effort is directed toward development of consistent risk factors for use by federal agencies. Dr. Robert G. Thomas was appointed Chairman of the Subpanel upon the retirement of the previous Chairman, Dr. Aurel Goodwin.

\section{NEUTRON QUALITY FACTOR}

The Science Subpanel on the Scientific Basis of Radiation Protection Standards continued revision of its report on Neutron Quality Factor in response to comments received from members of the Science Panel and others. The revised report is expected to be submitted to the Science Panel in September 1989. 
IV. REPORTS COMPLETED 1984-1989

- DVA Assessment of Veterans with Military Service at Sites of Temporarily Augmented Ionizing Radiation

- Review of the Draft Report of the National Institutes of Health Ad Hoc Working Group to Develop Radioepidemiological Tables

- Review of the Report of the National Institutes of Health Ad Hoc Working Group to Develop Radioepidemiological Tables

- Report on Identification of Federal Radiation Issues

- International Activities Report

- Radon Protection and Health Effects

- $\quad$ SI Metric Radiation Units

- Update of the International Activities Report

- The Federal Ionizing Radiation Research Agenda Related to Low Level Biological Effects: FY85

- Review of Scope 28 Report on Environmental Consequences of Nuclear War: Volume II, Ecological and Agricultural Effects

- Federal Programs on Indoor Radon

- Use of Probability of Causation by the Veterans Administration in the Adjudication of Claims of Injury Due to Exposure to Ionizing Radiation

- A Compendium of Major U.S. Radiation Protection Standards and Guides: Legal and Technical Facts

- Report of the Ad Hoc Planning Group 
V. ORGANIZATION AND REPORTING STRUCTURES

A. EXECUTIVE COMMITTEE

\author{
Chairman \\ Dr. Alvin L. Young \\ Department of Agriculture
}

Vice Chairman

Mr. Richard J. Guimond

Environmental Protection Agency

Executive Secretary

Mr. Robert L. Brittigan

Department of Defense

Chairman, Science Panel

Dr. Randall S. Caswell

Department of Commerce

Vice Chairman, Science Panel

Dr. Marvin Rosenstein

Department of Health \& Human Services

Executive Secretary, Science Panel

Dr. Percival D. McCormack

National Aeronautics \& Space Administration

Technical Assistance Director

CAPT Jay G. McDonald

Department of Energy

Mr. Thaddeus J. Dobry, alt.

Department of Energy 


\section{B. CIRRPC MEMBER AGENCIES AND REPRESENTATIVES}

Department of Agriculture

Dr. Mary E. Carter

Dr. James W. Glosser, alt.

Dr. Jane F. Robens"

Dr. Ronald Engel* (alt.)

Department of Commerce

Mr. Raymond G. Kammer

Dr. Randall S. Caswell, alt.

Mr. Charles M. Eisenhauer*

Dr. George P. Lamaze" (alt.)

Department of Defense

Dr. Robert B. Barker

V ADM J.T. Parker, alt.

Mr. R. Thomas Bell

COL George Irving, III* (alt.)

Department of Energy

Mr. Ernest C. Baynard, III

Dr. Richard Starostecki, alt.

Dr. Robert W. Wood"

Dr. Robert G. Thomas" (alt.)

Department of Health \& Human

Services

Mr. John C. Villforth

Dr. Marvin Rosenstein, alt.

Dr. Gilbert W. Beebe"

Dr. Bruce W. Wachholz" (alt.)

- Denotes Science Panel Members
Department of Housing \& Urban

Development

Mr. Richard H. Broun

Mr. James F. Miller"

(alt. for Policy Panel)

Mr. Joel Segal" (alt.)

\section{Department of Interior}

Dr. Eugene Roseboom, Jr.

Mr. Allan B. Tanner"

Department of Justice

Mr. Brent Hatch

Mr. Jeffrey Axelrad, alt.

Department of Labor

Mr. Robert E. Copeland

Ms. Margie E. Zalesak, C.I.H.

(alt. for Policy and Science)

Dr. Sheldon R. Weiner

Department of State

Dr. Charles M. Newstead

Department of Transportation

Ms. Elaine E. Joost

Mr. Michael E. Wangler"

(alt. for Policy Panel)

Ms. Kristen S. Smith" (alt.) 
Department of Veterans Affairs

Mr. Donald L. Ivers

Mr. Robert E. Coy, alt.

Dr. James J. Smith

Dr. Lawrence B. Hobson" (alt.)

Environmental Protection Agency

Mr. Richard J. Guimond

Mr. David E. Janes*

Dr. Jerome Puskin" (alt.)

Federal Emergency Management Agency

Mr. Dennis H. Kwiatkowski

Mr. Craig Wingo, alt.

Mr. Vernon Adler, alt.

Mr. Marlow J. Stangler"

Mr. George C. Meyer" (alt.)

Mr. Michael S. Pawlowski" (alt.)

National Aeronautics and Space Administration

Mr. Leven B. Gray

Mr. Robert H. Thompson, alt.

Dr. Percival D. McCormack"

Mr. E. G. Stassinopoulos" (alt.)

Nuclear Regulatory Commission

Dr. Denwood F. Ross

Mr: Robert Bernero, alt.

Dr. Donald A. Cool

Office of Management and Budget

Dr. Judith Bostock

Office of Science and Technology Policy

Dr. Robert Post

\section{POLICY AND SCIENCE} SUBPANEL PARTICIPANTS

Policy Subpanel on Radioepidemiological Tables

Dr. Robert B. Barker, DOD

(Chairman)

Mr. Robert Brittigan, DOD

(Alternate Chairman)

Mr. Richard Staufenberger, DOL

Ms. Ruth Berger, DOL, alt.

Mr. Richard J. Riseberg, HHS

Mr. Bob Lanham, HHS, alt.

Ms. Sandra Schneider, DOE/GC

Science Subpanel on High-LET Radiation

Dr. Bruce W. Wachholz, HHS

(Chairman)

Dr. J. Joseph Coyne, DOC

Dr. D. Stuart Nachtwey, NASA

CMDR Gary H. Zeman, DOD

Dr. Lawrence S. Myers, Jr., consultant

Task Group on High-LET Radiation

Dr. George W. Casarett, Chairman

University of Rochester Medical Center

Dr. Leslie A. Braby

Battelle Pacific Northwest Laboratories

Dr. Johan Broerse

TNO Radiobiological Institute

The Netherlands

Dr. Mortimer M. Elkind

Radiology and Radiation Biology

Colorado State University

Dr. Dudley Goodhead

Medical Research Council

United Kingdom

Dr. Nancy L. Oleinick

Division of Biochemical Oncology

University Hospitals 
Science Subpanel on Scientific Basis for Radiation Protection Standards

Mr. David Janes, EPA

(Chairman)

Dr. Elmer Eisenhower, DOC

Dr. Robert G. Thomas, DOE

CAPT David George, DOD

Mr. Kenneth Groves, consultant

Science Subpanel on Pre-Disaster Planning for Human Health Effects Research

Mr. Charles M. Eisenhauer, DOC

(Chairman)

Dr. Thomas MacVittie, DOD

Dr. Robert Young, DOD

Dr. Robert Goldsmith, DOE

Mr. James A. Martin, NRC

Dr. Gilbert Beebe, HHS, consultant

Dr. Frank Hassler, DOT, consultant

Dr. Clarence C. Lushbaugh, ORAU, consultant

Dr. Jocelyn Mitchell, NRC, consultant

Dr. Daniel Weiss, consultant

Mr. Robert Wilkerson, consultant

Working Group to Address NARM Regulations

Dr. Mary Carter, USDA

(Chairman)

Mr. R. Thomas Bell, DOD

Dr. Sheldon R. Weiner, DOL

Dr. J. William Gunter, EPA

Dr. John H. Austin, NRC

Mr. Donald Thompson, FDA

Mr. John Maddox, DOE

Dr. William H. Blahd, DVA

Mr. Floyd L. Galpin, EPA, alt.

MR. Kenneth Ferlic, DOE, alt.

Mr. Alan K. Roecklein, NRC, alt.

CDR William J. Flor, Ph.D., DOD, alt.
Science Subpanel on Occupational Radiation Protection Research

Mr. R. Thomas Bell, DOD

(Chairman)

Mr. John Clatworthy, DOE

Mr. Lemoine J. Cunningham, NRC

Ms. Jeannine T. Lewis, HHS

Dr. Percival D. McCormack, NASA

Dr. DeVaughn Nelson, DOE

Mr. Alan K. Roecklein, NRC

Dr. Sheldon R. Weiner, DOL

Dr. Matt Varma, DOE

Mr. Robert Alexander, consultant/liaison

Mr. Charles M. Hardin, consultant/liaison

Science Subpanel on Use of BEIR V and UNSCEAR 1988 in Risk Assessments

Dr. Marvin Rosenstein, HHS

(Chairman)

CDR William J. Flor, Ph.D., DOD

Dr. Gilbert W. Beebe, HHS

Mr. Kenneth P. Ferlic, DOE

Dr. Daniel Hoffman, HHS

Mr. Christopher Nelson, EPA

Dr. Frank J. Congel, NRC

Science Subpanel on Ionizing Radiation Risk Assessment

Dr. Robert Thomas, DOE

(Chairman)

Dr. Richard A. Albanese, DOD

Dr. James Smith, HHS

Dr. Shlomo Yaniv, NRC

Dr. Jerome Puskin, EPA 
D. ORAU TECHNICAL ASSISTANCE STAFF

Anthony H. Ewing

Program Director

Sandra J. Nessel

Executive Secretary

Darlene Thompson

Meeting Coordinator
William A. Mills

Sr. Technical Advisor

David S. Smith

Technical Analyst

Diane S. Flack

Technical Specialist

Elaine L. Doggett

Sr. Technical Secretary

Brenda Campbell

Technical Secretary

Edward E. Cour

Sr. Administrative Officer

Leonard A. Ceruzzi, Jr.

Computer Specialist

June Wiley

Office Assistant

Marnie Mihalik

Receptionist 


\section{E. CIRRPC ORGANIZATION}

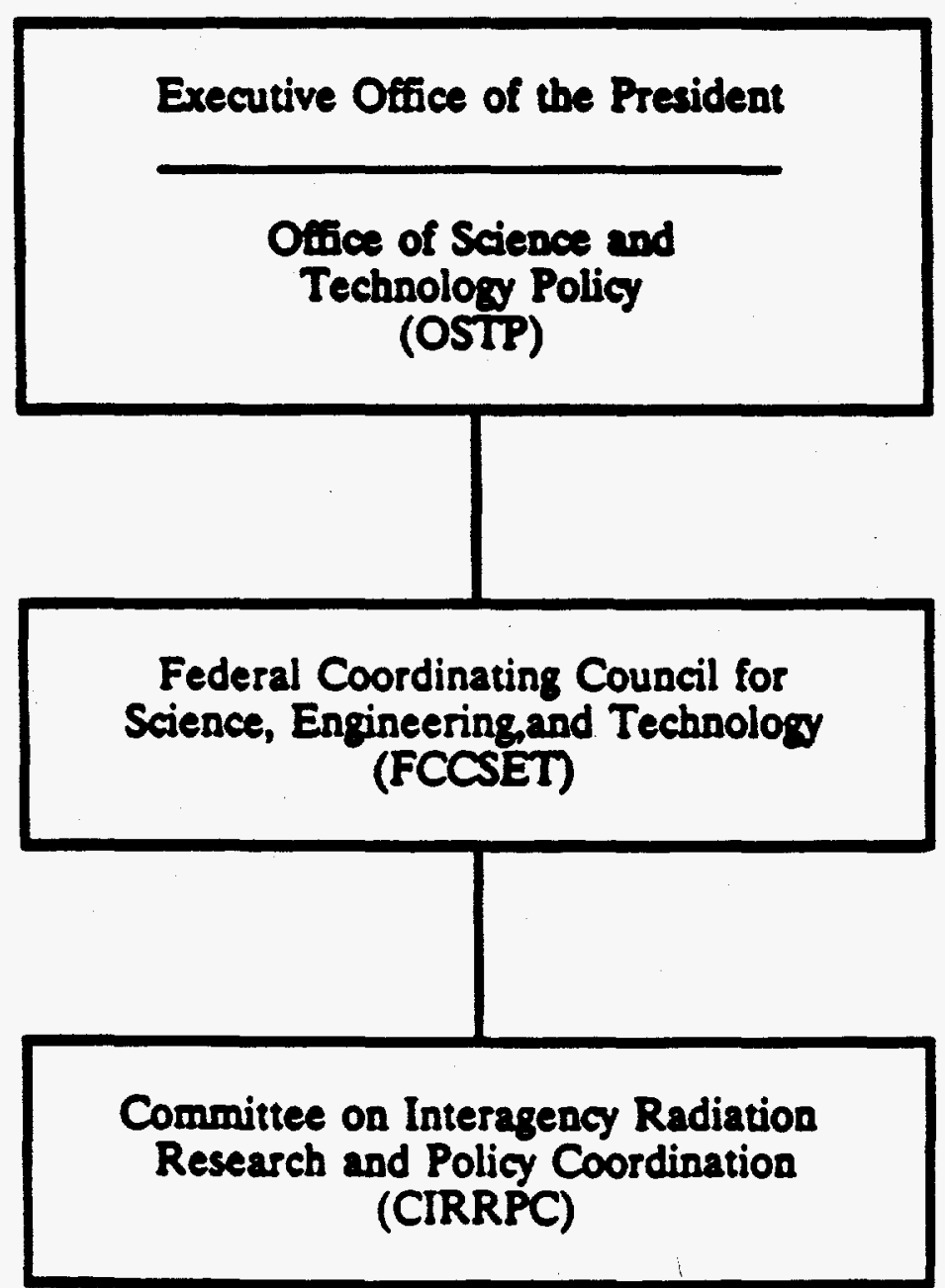


